\title{
OTITIS MEDIA SUPURATIF AKUT DI POLIKLINIK THT-KL BLU RSU. PROF. DR. R. D. KANDOU MANADO PERIODE JANUARI 2010-DESEMBER 2012
}

\author{
William Palandeng \\ Olivia Pelealu \\ Steward Mengko
}

\author{
Bagian Ilmu Kedokteran Telinga Hidung dan Tenggorokan Fakultas Kedokteran \\ Universitas Sam Ratulangi Manado \\ Email: william_palandeng@rocketmail.com
}

\begin{abstract}
Acute suppurative otitis media (ASOM) is an acute inflammation of the middle ear that lasted less than three weeks. The age factor is one of the risk factors associated with the ASOM. Children are more susceptible to ASOM, where the frequency will decrease with age. From the research ASOM most vulnerable to children due to tubal eustachius in children horizontally straight,shorter and wide. This research uses descriptive method through retrospective medical record in Ear, Nose, Throat-Head and Neck Surgery Department of Prof. R. D. Kandou General Hospital Manado on the period January 2010-December 2012.
\end{abstract}

keywords: Acute Suppurative Otitis Media, age, clinical symptoms

\begin{abstract}
Abstrak: Otitis media supuratif akut (OMSA) merupakan inflamasi akut telinga tengah yang berlangsung kurang dari tiga minggu. Faktor usia merupakan salah satu faktor resiko yang cukup berkaitan dengan terjadinya OMSA. Anak-anak lebih rentan terkena OMSA, dimana frekuensinya akan berkurang seiring dengan pertambahan usia. Dari hasil penelitian anak paling mudah terserang OMSA karena tuba eustachius pada anak lebih lurus secara horizontal,lebih pendek dan lebar. Penelitian ini menggunakan metode retrospektif deskriptif melalui rekam medik di poliklinik THT-KL RSU. Prof. Dr. R. D. Kandou Manado periode Januari 2010Desember 2012.
\end{abstract}

Kata kunci: Otitis media supuratif akut, usia, gejala klinik

OMSA merupakan inflamasi akut telinga tengah yang berlangsung kurang dari tiga minggu. ${ }^{1}$ Telinga tengah adalah ruang di dalam telinga yang terletak antara membran timpani dengan telinga dalam serta berhubungan dengan nasofaring melalui tuba Eustachius. $^{2}$

Faktor usia merupakan salah satu faktor resiko yang cukup berkaitan dengan terjadinya OMSA. Kasus OMSA secara umum banyak terjadi pada anak-anak dibandingkan kalangan usia lainnya. Kondisi demikian terjadi karena faktor anatomis, dimana pada fase perkembangan telinga tengah saat usia anak-anak, tuba Eustachius memang memiliki posisi yang lebih horisontal dengan drainase yang minimal dibandingkan dengan usia lebih dewasa. ${ }^{2}$

Anak-anak berusia 6-11 bulan lebih rentan terkena OMSA, dimana frekuensinya akan berkurang seiring dengan pertambahan usia, yaitu pada rentang usia 18-20 bulan. Pada usia yang lebih tua, beberapa anak cenderung tetap mengalami OMSA dengan persentase kejadian yang cukup kecil dan terjadi paling sering pada usia empat tahun dan awal usia lima tahun. Kadang-kadang, individu dewasa yang tidak pernah memiliki riwayat penyakit telinga sebelumnya, namun mengalami Infeksi Saluran Pernafasan Atas 
(ISPA) yang disebabkan oleh adanya infeksi virus juga mengalami OMSA. Pada penelitian terhadap 112 pasien ISPA (6-35 bulan), didapatkan 30\% mengalami otitis media supuratif akut dan $8 \%$ sinusitis. Epidemiologi seluruh dunia terjadinya otitis media berusia 1 tahun sekitar 62\%, sedangkan anak-anak berusia 3 tahun sekitar 83\%. Di Amerika Serikat, diperkirakan 75\% anak mengalami minimal satu episode otitis media sebelum usia 3 tahun dan hampir setengah dari mereka mengalaminya tiga kali atau lebih. ${ }^{1,3}$

Di Eskimo sekitar 30\% anak-anak terkena OMSA dan ini adalah penyakit yang ditemukan pada ras Amerika Indian yaitu sebanyak 8099 penderita anak-anak dari 10000 penderita OMSA. Berbagai studi epidemiologi melaporkan angka prevalensi dari OMSA menjadi 17-20\% dalam 2 tahun pertama kehidupan. OMSA adalah penyakit berulang. Sepertiga dari anak mengalami 6 atau lebih episode OMSA hingga usia 7 tahun. ${ }^{4,5}$

\section{METODE PENELITIAN}

Jenis penelitian ini adalah retrospektif deskriptif. Penelitian dilaksanakan pada bulan November 2012 sampai dengan Desember 2012. Penelitian dilaksanakan di Poliklinik THT-KL BLU RSU Prof. Dr. R. D. Kandou Manado. Populasi adalah pasien yang berobat di Poliklinik THT-KL BLU RSU Prof. Dr. R. D. Kandou Manado periode Januari 2010 - Desember 2012. Sampel adalah pasien yang terdiagnosis OMSA pertama kali (baru) di Poliklinik THT-KL BLU RSU Prof. Dr. R. D. Kandou Manado periode Januari 2010 - Desember 2012.

Penderita OMSA adalah pasien yang terdiagnosis OMSA pertama kali (kasus baru) di Poliklinik THT-KL BLU RSU Prof. Dr. R. D. Kandou Manado dalam periode Januari 2010 - Desember 2012.

\section{HASIL PENELITIAN}

Tabel 1. Distribusi penderita OMSA berdasarkan tahun di poliklinik THT-KL BLU RSU Prof. DR. R. D. Kandou Manado periode Januari 2010-Desember 2012

\begin{tabular}{cccc}
\hline Tahun & $\begin{array}{c}\text { Jumlah } \\
\text { Penderita } \\
\text { Baru }\end{array}$ & $\begin{array}{c}\text { Jumlah } \\
\text { Penderita } \\
\text { Diagnosis OMSA }\end{array}$ & \% \\
\hline 2010 & 5914 & 68 & $1.1 \%$ \\
2011 & 5180 & 58 & $1.1 \%$ \\
2012 & 5217 & 46 & $0.9 \%$ \\
Total & 16311 & 172 & $1.0 \%$ \\
\hline
\end{tabular}

Tabel 2. Distribusi penderita OMSA berdasarkan jenis kelamin di poliklinik THT-KL BLU RSU Prof. Dr. R. D. Kandou Manado periode Januari 2010-Desember 2012

\begin{tabular}{lcccccc}
\hline \multirow{2}{*}{ Jenis } & \multicolumn{2}{c}{$\mathbf{2 0 1 0}$} & \multicolumn{2}{c}{$\mathbf{2 0 1 1}$} & \multicolumn{2}{c}{$\mathbf{2 0 1 2}$} \\
Kelamin & $\mathrm{N}$ & $\%$ & $\mathrm{~N}$ & $\%$ & $\mathrm{~N}$ & $\%$ \\
\hline Laki-laki & 31 & $46 \%$ & 26 & $45 \%$ & 24 & $52 \%$ \\
Perempuan & 37 & $54 \%$ & 32 & $55 \%$ & 22 & $48 \%$ \\
Total & 68 & $100 \%$ & 58 & $100 \%$ & 46 & $100 \%$ \\
\hline
\end{tabular}

Tabel 3. Distribusi penderita OMSA berdasarkan umur di poliklinik THT-KL BLU RSU Prof. Dr. R. D. Kandou Manado periode Januari 2010-Desember 2012

\begin{tabular}{|c|c|c|c|c|c|}
\hline \multirow{2}{*}{$\begin{array}{l}\text { Golongan } \\
\text { Umur } \\
\text { (Tahun) }\end{array}$} & \multicolumn{3}{|c|}{ Tahun } & \multirow[b]{2}{*}{ Jumlah } & \multirow[b]{2}{*}{$\%$} \\
\hline & 2010 & 2011 & 2012 & & \\
\hline$<5$ Thn & 24 & 10 & 20 & 54 & $31 \%$ \\
\hline 5-14 Thn & 8 & 8 & 6 & 22 & $13 \%$ \\
\hline $\begin{array}{l}\text { 15-24 } \\
\text { Thn }\end{array}$ & 5 & 5 & 2 & 12 & $7 \%$ \\
\hline $\begin{array}{l}25-34 \\
\text { Thn }\end{array}$ & 10 & 7 & 3 & 20 & $12 \%$ \\
\hline $\begin{array}{l}\text { 35-44 } \\
\text { Thn }\end{array}$ & 6 & 10 & 4 & 20 & $12 \%$ \\
\hline $\begin{array}{l}45-54 \\
\text { Thn }\end{array}$ & 5 & 9 & 4 & 18 & $10 \%$ \\
\hline $\begin{array}{l}\text { 55-65 } \\
\text { Thn }\end{array}$ & 6 & 7 & 2 & 15 & $9 \%$ \\
\hline >65 Thn & 4 & 2 & 5 & 11 & $6 \%$ \\
\hline Total & 68 & 58 & 46 & 172 & $100 \%$ \\
\hline
\end{tabular}


Tabel 4. Distribusi penderita berdasarkan pekerjaan di poliklinik THT-KL BLU RSU Prof. R. D. Kandou Manado periode Januari 2010Desember 2012

\begin{tabular}{lcc}
\hline $\begin{array}{l}\text { Jenis } \\
\text { Pekerjaan }\end{array}$ & Jumlah & Persentasi \\
\hline Petani & 27 & $15 \%$ \\
Pelajar & 22 & $13 \%$ \\
Swasta & 17 & $10 \%$ \\
Pegawai & 15 & $9 \%$ \\
IRT & 20 & $12 \%$ \\
Pensiunan & 17 & $10 \%$ \\
Lain-lain & 54 & $31 \%$ \\
Jumlah & 172 & $100 \%$ \\
\hline
\end{tabular}

Tabel 5. Distribusi penderita OMSA berdasarkan gejala klinik di bagian poliklinik THT-KL BLU RSU Prof. Dr. R. D. Kandou Manado periode Januari 2010-Desember 2012

\begin{tabular}{|c|c|c|c|}
\hline Gejala Klinik & & Jumlah & Persentasi \% \\
\hline Otore & & 87 & $41 \%$ \\
\hline Nyeri telinga & & 47 & $22 \%$ \\
\hline $\begin{array}{l}\text { Pendengaran } \\
\text { berkurang }\end{array}$ & & 28 & $13 \%$ \\
\hline Tinitus & & 9 & $4 \%$ \\
\hline Demam & & 4 & $2 \%$ \\
\hline $\begin{array}{l}\text { Batuk } \\
\text { beringus }\end{array}$ & $\&$ & 30 & $14 \%$ \\
\hline Gejala Lain & & 11 & $5 \%$ \\
\hline Jumlah & & 216 & $100 \%$ \\
\hline
\end{tabular}

Tabel 6. Distribusi penderita OMSA berdasarkan lokasi di poliklinik THT-KL BLU RSU Prof. Dr. R. D. Kandou periode Januari 2010-Desember 2012

\begin{tabular}{lcc}
\hline Lokasi & Jumlah & Persentasi \% \\
\hline Unilateral & 131 & $76 \%$ \\
Bilateral & 41 & $24 \%$ \\
Total & 172 & $100 \%$ \\
\hline
\end{tabular}

Berdasarkan hasil penelitian di Poliklinik THT-KL BLU RSU Prof. R. D. Kandou Manado jumlah pengunjung yang datang berobat selama periode tahun (20102012) berjumlah 16.311 orang, 172 orang $(1,0 \%)$ ditemukan menderita OMSA. Pada tahun 2010 jumlah penderita 68 (1,1\%) dari Tabel 7. Distribusi Penderita OMSA berdasarkan jenis penanganan di poliklinik
THT-KL BLU RSU Prof. Dr. R. D. Kandou Manado periode Januari 2010-2012

\begin{tabular}{lll}
\hline $\begin{array}{l}\text { Jenis } \\
\text { Penanganan }\end{array}$ & Jumlah & Persentasi \\
\hline $\begin{array}{l}\text { Medika Mentosa } \\
\text { Tindakan Bedah }\end{array}$ & 171 & $99.5 \%$ \\
$\begin{array}{l}\text { Minor + Medika } \\
\text { Mentosa }\end{array}$ & 1 & $0.5 \%$ \\
\hline
\end{tabular}

5914 penderita yang baru dirawat. Setelah itu berturut-turut tahun 2011 sebanyak 58 (1,1\%) dari 5180 penderita baru, tahun 2012 sebanyak 46 penderita (0.9\%) dari 5217 penderita baru

Pada distribusi berdasarkan jenis kelamin didapatkan bahwa tidak ada perbedaan mencolok antara penderita lakilaki dan perempuan. Hasil penelitian menunjukan bahwa penderita laki-laki $(47,10 \%)$ lebih sedikit dari penderita perempuan (52,90\%). Namun antara lakilaki dan perempuan tidak didapatkan perbedaan yang signifikan, sehingga dapat disimpulkan bahwa penyakit ini tidak menyerang jenis kelamin tertentu.

Tabel 3 menunjukkan bahwa umur kurang dari 5 tahun dengan jumlah kasus terbanyak, yaitu 54 penderita (31\%). Hal ini sesuai dengan kepustakaan yang menyebutkan bahwa OMSA merupakan penyakit yang kebanyakan diderita anak-anak, terutama bayi dan anak kecil dibawah 2 tahun. Penyebabnya berhubungan dengan anatomi dimana tuba eustachius pada anak lebih lurus secara horizontal, lebih pendek, telinga bagian dalam dan tuba Eustachius yang belum berkembang dengan sempurna, sehingga bakteri, virus, dan iritan yang lain dengan mudah masuk ke telinga lewat tenggorokan. $^{2}$

Berdasarkan data tentang distribusi berdasarkan pekerjaan bahwa penderita petani dan pelajar paling sering menderita OMSA. Pada Periode Januari 2010Desember 2012, yaitu sebanyak 27 penderita pekerja petani (15\%) dan pelajar 22 (13\%). Mungkin ini masih berkaitan dengan belum adanya perbaikan kondisi sosial ekonomi masyarakat, kurangnya kesadaran dan pengetahuan tentang 
pentingnya kesehatan dari masyarakat khususnya mengenai OMSA, higiene dan sanitasi dari masing-masing individu, serta sarana-sarana kesehatan di berbagai tempat masih kurang.

Berdasarkan data yang diperoleh, keluhan utama terbanyak adalah keluar cairan telinga(otore) pada 87 kasus dari 216 total gejala klinik penderita OMSA (41\%). Hal ini mungkin terjadi karena kurangnya pengetahuan masyarakat dalam mengetahui tanda awal dari OMSA sehingga banyak penderita yang datang saat OMSA sudah pada stadium perforasi.

Berdasarkan data yang diperoleh, keluhan utama terbanyak adalah keluar cairan telinga(otore) pada 87 kasus dari 216 total gejala klinik penderita OMSA (41\%). Hal ini mungkin terjadi karena kurangnya pengetahuan masyarakat dalam mengetahui tanda awal dari OMSA sehingga banyak penderita yang datang saat OMSA sudah pada stadium perforasi.

Secara keseluruhan kasus OMSA, ditemukan jenis penanganan medika mentosa yakni dengan pemberian antibiotika, dekongestan, analgetik dan pemberian obatobat lainnya adalah jenis penanganan yang paling sering diberikan, yaitu sebanyak 171 penderita (99,5\%), sedangkan jumlah penderita yang mendapat tindakan bedah minor adalah sebanyak 1 Penderita (0,5\%).

Secara keseluruhan kasus OMSA, ditemukan jenis penanganan medika mentosa yakni dengan pemberian antibiotika, dekongestan, analgetik dan pemberian obatobat lainnya adalah jenis penanganan yang paling sering diberikan, yaitu sebanyak 171 penderita (99,5\%), sedangkan jumlah penderita yang mendapat tindakan bedah minor adalah sebanyak 1 Penderita (0,5\%).

\section{SIMPULAN}

Dari hasil penelitian dapat disimpulkan sebagai berikut :

1. Jumlah penderita OMSA sebanyak 172 penderita dari 16.311 penderita baru yang datang berobat periode Januari 2010-Desember 2012.
2. Ditemukan penderita OMSA terbanyak adalah berjenis kelamin perempuan.

3. Umur yang paling banyak menderita OMSA adalah kurang dari 5 tahun.

4. Jenis pekerjaan terbanyak adalah petani 27 penderita, di ikuti pelajar yaitu 22 penderita. Yang kedua hasil pesentasinya tidak jauh berbeda.

5. Gejala klinik otore gejala yang sering membawa penderita datang berobat khususnya pada bayi dan anak, diikuti dengan gejala klinik Nyeri telinga.

6. Lokasi OMSA unilateral lebih banyak dibandingkan dengan bilateral.

7. Jenis penanganan medika mentosa adalah jenis penanganan yang sering di berikan yaitu sebanyak 171 kasus dari 172 penderita OMSA.

\section{SARAN}

Setelah melakukan penelitian secara retrospektif di Poliklinik THT-KL BLU RSU Prof. Dr. R. D. Kandou Manado periode Januari 2010 - Desember 2012, maka penulis menyarankan:

1. Perlunya penyempurnaan sistem pencatatan dan penyimpanan data pasien.

2. Diharapkan penelitian ini dapat dijadikan sebagai langkah awal bagi penelitianpenelitian berikutnya dalam menentukan diagnosis Otitis media supuratif akut (OMSA).

\section{UCAPAN TERIMA KASIH}

Terima kasih kepada dr. Olivia C. Pelealu, SpTHT-KL sebagai dosen penguji I, dr. R. E. C. Tumbel, SpTHT-KL sebagai dosen penguji II, serta kepada seluruh pihak yang telah membantu baik secara langsung maupun tidak langsng yang telah menumbuhkan ide dan gagasan sehingga artikel ini telah selesai. 
650 Jurnal e-Biomedik (eBM), Volume 1, Nomor 1, Maret 2013, hlm. 646-650

\section{DAFTAR PUSTAKA}

1. Donaldson JD. Acute otitis media. Journal of medicine [online]. 2011 [cited 2012 Oct 26]. Available

from:

http://emedicine.medscape.com/article/85931 6-over view\#a0104.

2. Tortora GJ, Derrickson BH. Principles of Anatomy and Physiology (12th Edition) International Student Version Volume 1. Hoboken: John Wiley and Sons, Inc, 2009; p.620-1.

3. Revai, Krystal et al. Incidence of Acute
Otitis Media and Sinusitis Complicating Upper Respiratory Tract Infection: The Effect of Age. PEDIATRICS. 2007;119 (6):e1408-12.

4. Waseemn M. Otitis media. Jurnal Ilmu Pendidikan Kedokteran [online]. 2010 [cited2012 Oct 21]. Available from: http://www.emedicine.medscape.com/article/ 994656- overview\#showall.

5. Ballenger JJ. Diseases of the Nose, Throat, Ear, Head and Neck (13th Edition). Philadelphia: Publisher?, 1985; p.1128-34. 